\title{
Developing Urban Environment by Focusing on Human Thermal \& Wind Comfort: A literature review
}

\author{
Zahra Ghasemi ${ }^{1}$, Mahnaz Asemi Esfahani ${ }^{1}$, Mona Bisadi² \\ ${ }^{1}$ School of Architecture and Environmental Design, \\ Iran University of Science and Technology, Tehran, 16846-13114, Iran \\ ${ }^{2}$ Islamic Azad University, West branch of Tehran, Iran
}

zahra.ghasemi88@yahoo.com

\begin{abstract}
This paper survey importance of urban open spaces and effective parameters on people attendance. In the recent years, low-quality environments have caused a low level of people attendance in that places and subsequently, lots of different problems in human life. One of the determining factors affecting the quality of the environment is providing human comfort. This paper discusses human comfort features. The aim of this article is presentation guidelines based on the creation of the wind and thermal comfort in urban open spaces. According to the fact, by the presence of comfort we can return people to urban open spaces. We derived some conceptual frameworks and categorized them on a chart. The table is divided into four climatic regions based on Iran climatology, to lead architects, urban planners for designing desirable spaces.
\end{abstract}

Keywords: Comfort zone; urban environment; public open space; quality of life (QOL)

eISSN 2514-7528 @ 2018. The Authors. Published for AMER ABRA cE-Bs by e-International Publishing House, Ltd., UK. This is an open-access article under the CC BY-NC-ND license (http://creativecommons.org/licenses/by$n c-n d / 4.0 /$ ). Peer-review under responsibility of AMER (Association of Malaysian Environment-Behaviour Researchers), ABRA (Association of Behavioural Researchers on Asians) and cE-Bs (Centre for EnvironmentBehaviour Studies), Faculty of Architecture, Planning \& Surveying, Universiti Teknologi MARA, Malaysia.

DOI: https://doi.org/10.21834/jabs.v3i10.305 


\subsection{Introduction}

The quality of life (QOL) is a multi-aspect criterion that is related to life satisfaction, need satisfaction and happiness (Mohit, 2013). As concerns have increased in QOL, lots of community indicators have attempted to its measurement and improvement (Ayman Mohamad, 2012). Nevertheless, there are few studies in the literature of QOL that have focused on branches of the environment such as architecture, landscape, and urban design (Mohit 2013; Nadzira, Ibrahima, \& Mansor 2014). Whereas decreased levels of people attendance within urban built environments, have caused interaction deficiency and a low level of QOL subsequently. So that, QOL-related research in the urban environment is recommended to be embedded in the design (Mohit, 2013). Ascertaining QOL, specifically through the environment is a significant task of architects, designers and urban planners (Ibrahim Bajunid, et al., 2014). Deterioration of quality of environments have a direct influence on human's QOL or even on threatening the survival of humankind (Hitam and Borhanb, 2012; Syariazulfa Kamaruddin, Fadhil Mohammad, \& Mahbub, 2013).

In the recent years, low-quality environments have caused lots of different problems in various aspects of humans' lives. It has led to the undesirable conditions in cities, for instance, reduction of safety, vitality, and liveliness. It's necessary to study and plan for new cities and communities before their development, to guide them in management, designing and achieve sustainable societies (Mwirigi M'Ikiugu, QianNa, \& Kinoshita, 2012). One of the important issue which affect human health is Environmental Health that concern all aspect of built and natural environment. The association between urban planning and environmental health is because of the major intention in urban planning, to achieve a healthy and sustainable environment (Ayuni Shafie, Omar, \& Karuppannan, 2013) to benefit the city from various sides such as social aspects (Jamaludin \& Begam Yusof, 2013).

Public space has been always considered as a reflection of the social status of the community. More ever, it can increase the social sustainability (El-Husseiny \& Kesseiba, 2012). Public open spaces have essential effects on people's QOL (Chen \& Ng, 2012; Nikolopoulou \& Lykoudis, 2006). It's necessary to promote suitable urban open spaces to create positive changes in society. A lot of Studies point out the importance of open spaces and green areas of built environment in the motivation of humankind to attend such places and interact with the other (Nikolopoulou \& Lykoudis, 2007). As studies revealed, open spaces provide the opportunity for people in different ages, especially children, and elderly populations, to interact with other people and to spend their leisure time in that areas (Gómez, Pérez Cueva, \& Valcuende, 2013). Urban parks are such ideal locations that cause to improve human well-being and provide opportunities for physical activities (Adawiyah Nasir, Ahmad, \& Zain Ahmed, 2013). The design of these kinds of built environment should be in a way that encourage people to walk and interact (Raja Ariffin \& Khairi Zahari, 2013). Subsequently, restoration of ignored interaction is possible by considering people's desirable open spaces that have high quality in construction (Janipha \& Ismail, 2013). The quality of the environment is categorized into various sections, that human comfort is the most important one. There is a significant relation among QOL, human comfort and urban built 
environment (Nadzira, Ibrahima, \& Mansor, 2014). Hence, Creation of comfort zone in outdoor open spaces is one of the essential elements to overcome this problem (Nikolopoulou, Baker, \& Steemers, 2001; Lai, Zhou, \& Huang, 2014).

\subsection{Human comfort}

In the twentieth century, the interaction of comfort with urban design was one of the interesting fields of study (Gómez, et al., 2013), due to the direct relation between urban design and QOL. The experiences demonstrate that cities include comfortable outdoor spaces, are more sustainable which can improve QOL (Chen \& Ng, 2012). Rapid urbanization without concerning guidelines of urban designing have caused losing the sustainable design of outdoor live (Khandaker Shabbir, 2003). However, the creation of comfort zone is necessarily related to the presence of a sustainable city (Lawson, 2013). Human comfort is related to biometeorological parameters, and it will be different under distinct climate. There are some factors that influence human comfort in other urban zones. For instance littoral and tropical zones (Xu, et al., 2010; Stathopoulosa, Wu, \& Zacharias, 2004; Taleghani, Kleerekoper, \& Tenpieri, 2014).

\subsection{Parameters of outdoor comfort}

There are lots of different parameters incorporated in the human comfort of outdoor spaces. A wide range of variables affect human comfort; including air temperature, solar radiation, wind speed, air flow, humidity, clothing level, acoustic (Stathopoulosa, Wub, \& Zachariasc, 2004; Givonia, Noguchib, \& Saaronic, 2003; Walton, 2007; Van Hovea, et al., 2015). This article divides these parameters into two major fields of thermal comfort and wind comfort that are dependent. However, they should consider as a unique course to determine satisfaction (Stathopoulosa, et al., 2004). Providing comfortability in urban open spaces in discomfort situation is done by human's adoption to the surrounding conditions. It could happen by limiting the time of exposure, changing the seating place, changing the clothing and, etc. the desired condition is one which can minimize the necessity for adjustment. To illustrate its significant effect, increasing climate temperature during the day discourage human to stay in urban outdoor spaces or to adapt themselves to environment by decreasing their clothing or changing the space to a shaded area by mandatory (Ngesan, Abdul Karim, \& Zubir, 2012). Hence, to achieve the desired open space some overall guideline is necessary. This study surveyed Relative effects of thermal and wind comfort and their deficiency to attain guideline for overall human comfort (Lai, et al., 2014). The aim of this article is deriving frameworks and providing some guideline for the purposeful design of compatible and appropriate open spaces in regards of the comfort zone. So that asserting related solution to the thermal and wind comfort is necessary. It will conclude return of people to such spaces to interact with another which cause improvement in quality of their life. Lots of researches have been done in the human comfort field, which could be divided into two types of human comfort in indoor and outdoor spaces. A lot of researchers studies pedestrians wind comfort, thermal comfort, quality of cities and environment and human comfort in different climate and microclimate in the outdoor space. Regards to the importance 
of the wind and thermal comfort and its effects on human comfort, in spite of their impact on each other, deserve investigations, all of these explores just focuses on a particular subject. No studies have been done on the overall wind and thermal comfort and their mutual effects on the local climate of Iran in Asia. In this paper through a multi-disciplinary review of the literature, we have collected lots of frameworks and guidelines to provide new design concepts of urban built environments for architects, urban planners, and designers. Finally, the paper is concluded with some recommendations for further research in this field.

\subsection{Methodology}

The literature review discusses influential factors on human comfort and the ways to achieve comfort in outdoor spaces. Literature was selected from different disciplines consisting of architecture, urban design, environmental knowledge, human science, Arts, and Humanities. In this paper some online database such as Google Scholar and Science Direct used to search for documents and other academic information from ajE-Bs (Asian Journal of Environment- Behavior Studies) and jABs (Journal of Asian Behavioural Studies). In these databases, certain keywords as a guideline have been searched including Comfort Zone, urban environment, and public open space.

For narrowing down the search, this paper determine filtering factors to choose appropriate and most relative articles to the main subject. The focal parameters of the article were the human comfort and urban spaces. Regarding the fact that human comfort has been categorized into various domains, we have chosen thermal and wind comfort. By the consideration of these categories, we've obtained some frameworks for each local climate of Iran which is one of the Asian countries. According to the books of Climate and Architecture by Kasmaei (2004) and climatology of Iranian traditional buildings by Ghobadian (2000), Iran has four climates of hot and dry, cold and dry, mild and humid and hot and humid. By the end of the article, all of the parameters were surveyed to present an overall guideline of thermal and wind comfort for each climate of Iran for urban planner and designers. In this way, we use analysis method to collect all data in a chart to survey the content of them and attain a framework.

\subsection{Thermal comfort}

\subsection{Importance of thermal comfort}

Among categorized parameters contributed to outdoor human comfort, thermal comfort is the most important one which is significant and determine quality of an outdoor space (Lai, Zhou, \& Huang, 2014; Chen \& Ng, 2012). Thermal comfort is a condition in which persons prefer neither warmer nor cooler temperatures, i.e., the ideal temperature (Rabiatul Adawiyah, Sabarinah Sh, \& Azni Zain, 2013). Surveys revealed that there is a direct relationship between thermal comfort in an urban space and amount of user's activity (Chen \& Ng, 2012). Most of the time pedestrians are exposed to the outdoor environment and its changes such 
as sunlight or shade. Generally speaking, environment affects people's tendency to stay or leave the place.

Outdoor thermal comfort is a complex issue. Microclimate and environmental conditions are vital factors for outdoor thermal comfort assessment (Chen \& Ng, 2012). Lots of studies were performed worldwide to compare different conditions in various climatic and urban spaces in many countries (Lai, Zhou, \& Huang, 2014; Johansson, Thorsson, Emmanuel, \& Krüger, 2013; Yang, Hien Wong, \& Kardinal Jusuf, 2013; Villadiego \& André Velay-Dabat, 2014). Many other investigations have been allocated for thermal sensation and effects of it on human comfort and user's activity. These have explored some ways to predict thermal comfort adoption in the environment based on the personal, environmental, psychological (habituation or expectation) and physiological variables (genetic adaptation or acclimatization). These variables affect thermal comfort and define some types of thermal comfort adaption (Yang, et al., 2013; Rabiatul Adawiyah, et al., 2013; Yang, et al., 2013; Chen \& Ng, 2012). Some studies have focused on these particular aspects of thermal comfort (Chen \& Ng, 2012; Johansson, et al., 2013). Most of these studies were performed on the subject of tropical cities because of the phenomenon of urbanization (Villadiego \& André Velay-Dabat, 2014). These investigations revealed that sunny or shady conditions effect on people's attendance in open spaces. In the 1980s, Berekly researchers worked on outdoor thermal comfort and provided some guidelines for the microclimate of San Francisco, which has led them to legislate some rules for solar access and wind comfort. By that time, a mathematical model was used to calculate thermal comfort (Nikolopoulou, et al., 2001).

\subsection{Effective parameters on thermal comfort}

There are numerous influential parameters on thermal comfort in the indoor and outdoor environment. These parameters examined by many investigators (Taleghani, et al., 2014). Attempts have been made to adjust outdoor thermal parameters by indoor parameters (Stathopoulosa, et al., 2004). There are lots of differences in indoor and outdoor criteria because of various climatic and environmental conditions (Stathopoulosa, et al., 2004). Accordingly, an indoor parameter cannot be used as an outdoor index (Johansson, et al., 2013). People in outdoor will have various experience because of some exposure condition (Givonia, et al., 2003).

Researchers who have made the first attempt to measure thermal comfort, named Howard, Hill, Griffith, and Doffon. These persons tried to measure mean radiant temperature, air temperature, air velocity and the equivalent temperature (Teq). Also, ASHRAE recommended using effective temperature (ET) while in 1971 Gagge presented $E T^{*}$ that is so perfect to covered radiation, convection, and evaporation. At the same time, Fengr proposed methods PMV (Predicted Mean Votes) and PPD (Predicted Percentage Dissatisfied) by the relation between feeling the heat and individual's ability on the basis of experimental results. These theories have made fundamental standards of thermal comfort (Taleghani, et al., 2014). 
Except some basic indices that are compatible with all climates and seasons, most of the effective factors on thermal comfort are different in various cities. It defines a mutual relationship between microclimates and thermal comfort (Xu, et al., 2010; van Hovea, et al., 2015). In general two methods are used to assess outdoor thermal comfort. One method is based on the heat balance of the human body named as the steady state model, and the other is based on the regression model. Steady-state model indices are categorized into two groups of indoor and outdoor. Predicted mean vote (PMV), effective temperature $\left(E T^{*}\right)$, and standard effective temperature $\left(\mathrm{SET}^{*}\right)$ are originally for indoor assessment. While physiological equivalent temperature (PET), OUT SET ${ }^{*}$ universal thermal climate index (UTCI), are developed for outdoor assessment. However physical, physiological, and psychological adaption should be considered before use of them for outdoor thermal comfort. The regression model defines outdoor thermal comfort by consideration of several climatic parameters such as air temperature, humidity, wind speed, global solar radiation, global temperature, and ground surface temperature (Taleghani, et al., 2014; Lai, et al., 2014).

The human body adapts itself to its surroundings. If the outdoor environment does not permit balancing the temperature, the thermal comfort will be hardly attained. In order to improve the thermal comfort level, it's necessary to increase the desirable heat flow and decrease the undesirable one (Gómez, et al., 2013). Nowadays we can simulate some parameters (Taleghani, et al., 2014). Environmental modeling tools such as ENVI-met, Town Scope, Rayman, and SOLWEIG can be used for thermal assessment and providing thermal indices perception (Chen \& Ng, 2012; Taleghani, et al., 2014). However, there is a need for predicting tool for urban designers to compare and test different alternatives (Chen \& Ng, 2012).

\subsection{Guidelines}

A comparison between various outdoor thermal comfort situations can generate clear guidelines for landscape and urban designers who want to create thermally comfortable outdoor climates.

- Selecting three main urban forms such as linear, singular and courtyard through careful studying on these types. Considering each type with a different compactness will provide various situations in their microclimate (Taleghani, Kleerekoper and Tenpieri, 2014).

- Study of the effect of various orientations of the urban canyon. It was concluded that the air temperature slightly decreases (and the PET improves) when the aspect ratio of building height/canyon width $(\mathrm{H} / \mathrm{W})$ increases (Taleghani, et al., 2014).

- Restriction of sun radiation by shading elements such as canopies covered buildings recesses and colonnades of walkways would be beneficial ( $\mathrm{Xu}$, et al., 2010).

- Using greening to reduce the thermal load in urban spaces. Plant leave's block sun radiation because of their transpiration. Use of Trees and their canopies, shrubs, 
flower beds and grass areas are the other useful ways to avoid thermal discomfort (Xu, et al., 2010; $\mathrm{Ng}$ and Cheng 2012).

- Studying and considering appropriate urban geometry that consist of different parameters such as height or building distances is another factor that determine the level of radiation or air flow. In this way, building's height, ratio between mean building height and mean street width, and the sky view factor (SVF) are some important factors to control thermal comfort (van Hovea, et al., 2015).

- Reducing temperature by evaporative cooling of water bodies such as Ponds, which has a significant role in thermal comfort, especially during the spring and summer (Gómez, et al., 2013; Xu, et al., 2010).

- Planting trees is one of the most important methods that can provide shading and acts as a barrier to solar radiation to provide thermal comfort specifically in the spring and summer. So that trees surrounding urban spaces such as street will be beneficial for providing thermal comfort (Gómez, Pérez Cueva, \& Valcuende, 2013). In planted areas, the thermal comfort level is, of course, more than nonplanted places. So that vegetation improves the thermal environment of urban space (Xu, et al., 2010).

- Improving thermal comfort through fountains with water jets, which can act as a cooling element by taking benefits of the spring or summer breezes (Gómez, et al., 2013).

- Using appropriate material for such places to avoid thermal stress in urban environments. For example, in the hot areas use of hard surfaces will increase solar reflection and higher heat load. Material colors also influence the thermal comfort because of the thermal absorption capacity of that specific material (Gómez, et al., 2013).

- Considering a compact urban design with a deep canyon is suitable for the summer, whereas a wider canyon is more appropriate for passive solar heating (Taleghani, et al., 2014).

- Designing a shaded area is a common preferable feature for open space during the summer, however creating a sunlit area is more prevalent during the autumn and winter (Taleghani, et al., 2014).

\subsection{Wind comfort}

\subsection{Importance of wind comfort}

Wind comfort is as essential as thermal comfort. One of the other important requirement for an urban environment is wind comfort and wind safety. They provide health and comfortability of pedestrians and defines as mechanical influence of the wind on human (Stathopoulosa, et al., 2004; Blocken, Janssen, \& Hooff, 2012).

The wind will effect on comfort, safety, distribution of heat, dispersion of excessive humidity, spreading of traffic and ventilation of buildings. It also can keep fresh air flow. It's 
important to perceive the pedestrian wind environment in urban spaces. Numerous studies have been done to improve environmental wind. These studies confirm that we can create favorable wind speed by appropriate designing and urban planning which lead us to desirable development (Wan Jabarudin \& Hanur Harith 2012; Ng \& Cheng 2012; Stathopoulosa, et al., 2004; van Hovea, et al., 2015; Blocken, et al., 2012; Xu, et al., 2010). For instance, high wind speed on pedestrian's level near the high-rise building, can make an uncomfortable and hazardous experience. Uncomfortable conditions may affect negatively on the success of new buildings and shops and may discourage the buyers from shopping anymore (Wan Jabarudin \& Hanur Harith 2012).

Nowadays many of the municipal authorities found out the importance of wind comfort for pedestrians. They encourage designers to make prior studies on the subjective of wind comfort before construction of new buildings in urban areas (Blocken, et al., 2012).

\subsection{Effective parameters on wind comfort}

In general wind comfort and wind safety studies include the combination of statistical meteorological data, aerodynamic information, wind comfort and wind safety criteria. Aerodynamic information is used to convert meteorological data of weather stations to the location of the site. At the location, local wind comfort and safety assessment will be performed by a combination of statistical information by comfort and safety criteria. Meteorological analyzes the express potential of wind speed by "Upot" index that result in some statistical data, i.e. equal to the aerodynamic roughness of the terrain with length $Z 0=$ $0.03 \mathrm{~m}$.
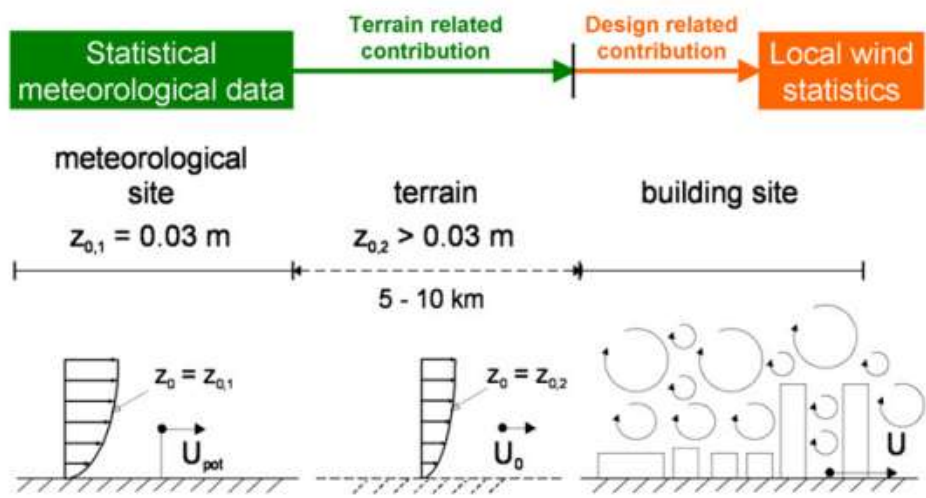

Fig.1. Graphic representation of alteration of statistical meterological data from the meteorological site to the building site

(Source: Blocken, Janssen and Hooff, 2012)

The aerodynamic information includes two major parts of the terrain related contribution and the design related contribution. The first part transfers Upot to $\cup 0$ that is wind changes from meteorological site to a reference location near the building site. The design related 
contribution transfers $\mathrm{U} 0$ to the local wind speed $\mathrm{U}$ which is representation of changes in wind statics (Blocken, et al., 2012; van Hovea, et al., 2015; Blocken \& Persoon, 2009).

There are many different criteria for wind speed and wind safety based on the threshold in various countries that are proportional to their location. Increasing the level of wind speed and air temperature will cause wind discomfort, so that chilling influence will bring back comfortability for space users (van Hovea, et al., 2015).

There are some ways to identify the wind condition that are wind tunnel and CFD method. These methods can recognize the wind effect on the buildings, structures, and pedestrian that are related to dispersion of heat and pollution. We can assess our build environment by the data derived from the results of wind tunnel and CFD testing (Wan Jabarudin \& Hanur Harith, 2012).

\subsection{Guidelines}

Attempts of some researchers in collecting the guidelines of wind comfort lead to some valuable investigation such as BPG (establishment of several sets of best practice guidelines), the Dutch Wind Nuisance Standard (NEN, 2006a) which helped to determine the appropriate experiment to choose the CFD or wind tunnel. Murakami and Morikawa (1985) proposed the wind velocity ranges during the summer, to elude thermal discomfort. It's because of some adverse attributes that cause insufficient and high-speed wind. In their suggestion, the limits of wind velocity are changed by increasing the daily mean temperature (Wan Jabarudin \& Hanur Harith, 2012; Blocken, et al., 2012).

In some cases, researchers stimulate their project in CFD or wind tunnel and then compare the results with previous standard research. In this situation, we carry out some general factors that are strategic decisions in the design.

These guidelines can suggest some useful design considerations for enhanced air ventilation. It can help designers to use a strategic solution for their scheme.

- Providing air flow in urban distinct to have better air condition especially in dense, hot and humid urban. By this way we can provide air flow to the surrounded area by high-rise buildings; moreover we can use open spaces, streets and the destination between low rise buildings. Hence, corridors should be designed in a way, not to obstacle anything.

- Providing the orientation of the streets to a line, up at parallel or up to 30 degrees to the prevailing wind direction. Hence, it will cause penetration of prevailing wind through the area.

- $\quad$ Linking open urban spaces in such way to form the corridors that cause airflow between them. We can do it with some roads, by the destination between low-rise buildings and linear parks.

- Locating a water body in front of sites can cause a desirable air flow in tropical cities while there isn't any obstacle to the wind flow.

- Providing maximum penetration of air flow by Coordination the longer frontage parallel to the wind direction. It is achievable by consideration of the orientation and 
development process. The development process is growing the tendency for developing the cities, because of crowded building masses and minimum spaces between buildings. Hence, providing non-building areas and setbacks where appropriate, is one of the key elements of urban design.

- Optimizing the potential of wind capturing, for example by reduction of the building height in the orientation of prevailing wind.

- Increasing air movement and dispersing the vehicles pollution by the setback of building based up to 15-meter height at street levels.

- Providing feasible, sufficient, and wide gaps between building blocks to increase the air movement.

- Removing the sign elevated walkways that obstacle the winds flow and work such as some blockage.

- $\quad$ Planting tall trees with wide and dense canopies along streets and open urban spaces, to increase pedestrian comfort and decrease the urban heat island effect.

- Using water body can also act as air cooler ( $\mathrm{Ng} \mathrm{2009).}$

- Avoiding Placement of building entrances in the corner part of the buildings, is the windiest part that make UN comfort wind.

- $\quad$ Considering shelter for high-rise buildings (Bottema 1999).

These guidelines help to have air condition and air flow in cities and open urban spaces. Hence, by using these methods, we can provide wind comfort in cities.

\subsection{Finding}

By the end of this article, we derive a chart that can help designers to improve the environment. The chart is categorized into four climate region of Iran such as hot and dry, cold and dry, mild and humid and hot and humid based on the books of Kasmaei (2004) and Ghobadian (2000).

Table 1. Frameworks

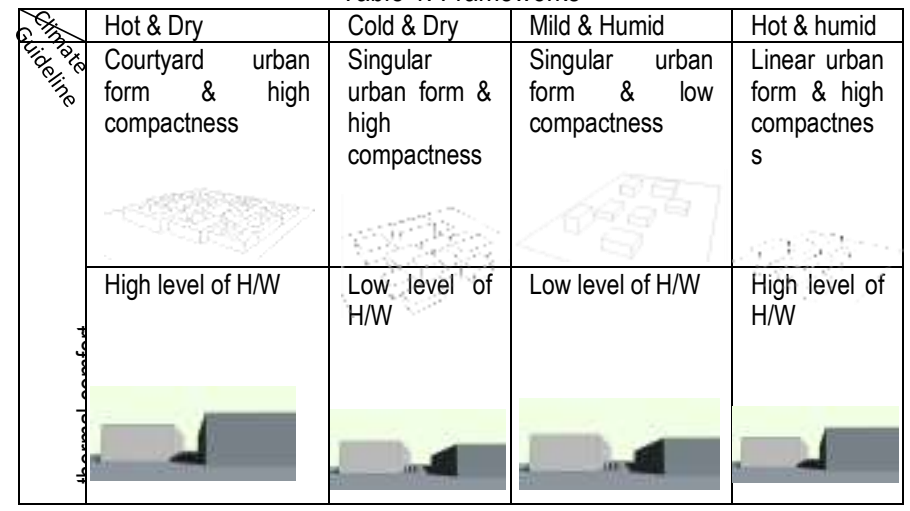




\begin{tabular}{|c|c|c|c|}
\hline $\begin{array}{l}\text { Restriction of sun } \\
\text { radiation }\end{array}$ & $\begin{array}{l}\text { Creation of } \\
\text { sunlit area }\end{array}$ & $\begin{array}{l}\text { Restriction of sun } \\
\text { radiation in hot } \\
\text { season }\end{array}$ & $\begin{array}{l}\text { Restriction of } \\
\text { sun radiation }\end{array}$ \\
\hline $\begin{array}{l}\text { Using greening, } \\
\text { Trees and their } \\
\text { canopies, shrubs, } \\
\text { flower beds and } \\
\text { grass areas and Use } \\
\text { of trees surrounding } \\
\text { urban spaces }\end{array}$ & $\begin{array}{l}\text { Using } \\
\text { deciduous } \\
\text { trees by } \\
\text { observance of } \\
\text { appropriate } \\
\text { distance from } \\
\text { building }\end{array}$ & $\begin{array}{lr}\text { Using } & \text { deciduous } \\
\text { trees } & \text { by } \\
\text { observance } & \text { of } \\
\text { appropriate } & \\
\text { distance } & \text { from } \\
\text { building } & \end{array}$ & $\begin{array}{l}\text { Using } \\
\text { greening, } \\
\text { Trees and } \\
\text { their } \\
\text { canopies } \\
\text { and Use of } \\
\text { trees } \\
\text { surrounding } \\
\text { urban } \\
\text { spaces }\end{array}$ \\
\hline $\begin{array}{l}\text { cooling of water } \\
\text { bodies }\end{array}$ & $\begin{array}{l}\text { evaporative } \\
\text { cooling of } \\
\text { water bodies }\end{array}$ & $\begin{array}{l}\text { cooling of water } \\
\text { bodies }\end{array}$ & $\begin{array}{l}\text { evaporative } \\
\text { cooling of } \\
\text { water bodies }\end{array}$ \\
\hline $\begin{array}{l}\text { Thermal mass, High } \\
\text { density, high time } \\
\text { lag materials }\end{array}$ & $\begin{array}{l}\text { Thermal } \\
\text { mass, } \\
\text { isolated, High } \\
\text { density, high } \\
\text { time lag } \\
\text { materials }\end{array}$ & $\begin{array}{l}\text { Low density \& } \\
\text { insolated } \\
\text { materials }\end{array}$ & $\begin{array}{l}\text { Low density } \\
\& \text { insolated } \\
\text { materials }\end{array}$ \\
\hline
\end{tabular}




\begin{tabular}{|c|c|c|c|c|}
\hline 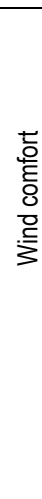 & $\begin{array}{l}\text { Providing air flow } \\
\text { plus evaporative } \\
\text { cooling }\end{array}$ & $\begin{array}{l}\text { Restriction of } \\
\text { air flow }\end{array}$ & $\begin{array}{l}\text { Use of open } \\
\text { spaces, streets } \\
\text { and the } \\
\text { destination } \\
\text { between low rise } \\
\text { buildings\& } \\
\text { Corridors } \\
\text { between buildings } \\
\text { to provide airflow } \\
\left({ }^{*} \mathrm{Ng}, 2009\right) \text {. }\end{array}$ & $\begin{array}{l}\text { Use of open } \\
\text { spaces, } \\
\text { streets and } \\
\text { the } \\
\text { destination } \\
\text { between low } \\
\text { rise } \\
\text { buildings\& } \\
\text { Corridors } \\
\text { between } \\
\text { buildings to } \\
\text { provide } \\
\text { airflow }\end{array}$ \\
\hline $\begin{array}{l}\text { t. } \\
\text { है } \\
0 \\
0 \\
\text { के } \\
\text { के }\end{array}$ & $\begin{array}{l}\text { Urban } \\
\text { across } \begin{array}{r}\text { Orientation } \\
\text { wind prevailing } \\
\text { evaporative cooling }\end{array}\end{array}$ & $\begin{array}{l}\text { Urban } \\
\text { Orientation in } \\
\text { opposite } \\
\text { direction of } \\
\text { prevailing } \\
\text { wind plus } \\
\text { evaporative } \\
\text { cooling }\end{array}$ & $\begin{array}{l}\text { Urban Orientation } \\
\text { across prevailing } \\
\text { wind } \\
\left({ }^{*} \mathrm{Ng}, 2009\right) .\end{array}$ & $\begin{array}{l}\text { Urban } \\
\text { Orientation } \\
\text { across } \\
\text { prevailing } \\
\text { wind }\end{array}$ \\
\hline & $\begin{array}{l}\text { Linking open urban } \\
\text { spaces } \\
\text { to form the corridors } \\
\text { between them } \\
\left({ }^{*} \mathrm{Ng}, 2009\right)\end{array}$ & $\begin{array}{l}\text { compacted } \\
\text { urban open } \\
\text { space }\end{array}$ & $\begin{array}{l}\text { Linking open } \\
\text { urban spaces } \\
\text { to form the } \\
\text { corridors between } \\
\text { them } \\
\left({ }^{*} \mathrm{Ng}, 2009\right)\end{array}$ & $\begin{array}{l}\text { Linking open } \\
\text { urban } \\
\text { spaces } \\
\text { to form the } \\
\text { corridors } \\
\text { between } \\
\text { them } \\
\\
\left.{ }^{*} \mathrm{Ng}, 2009\right)\end{array}$ \\
\hline
\end{tabular}




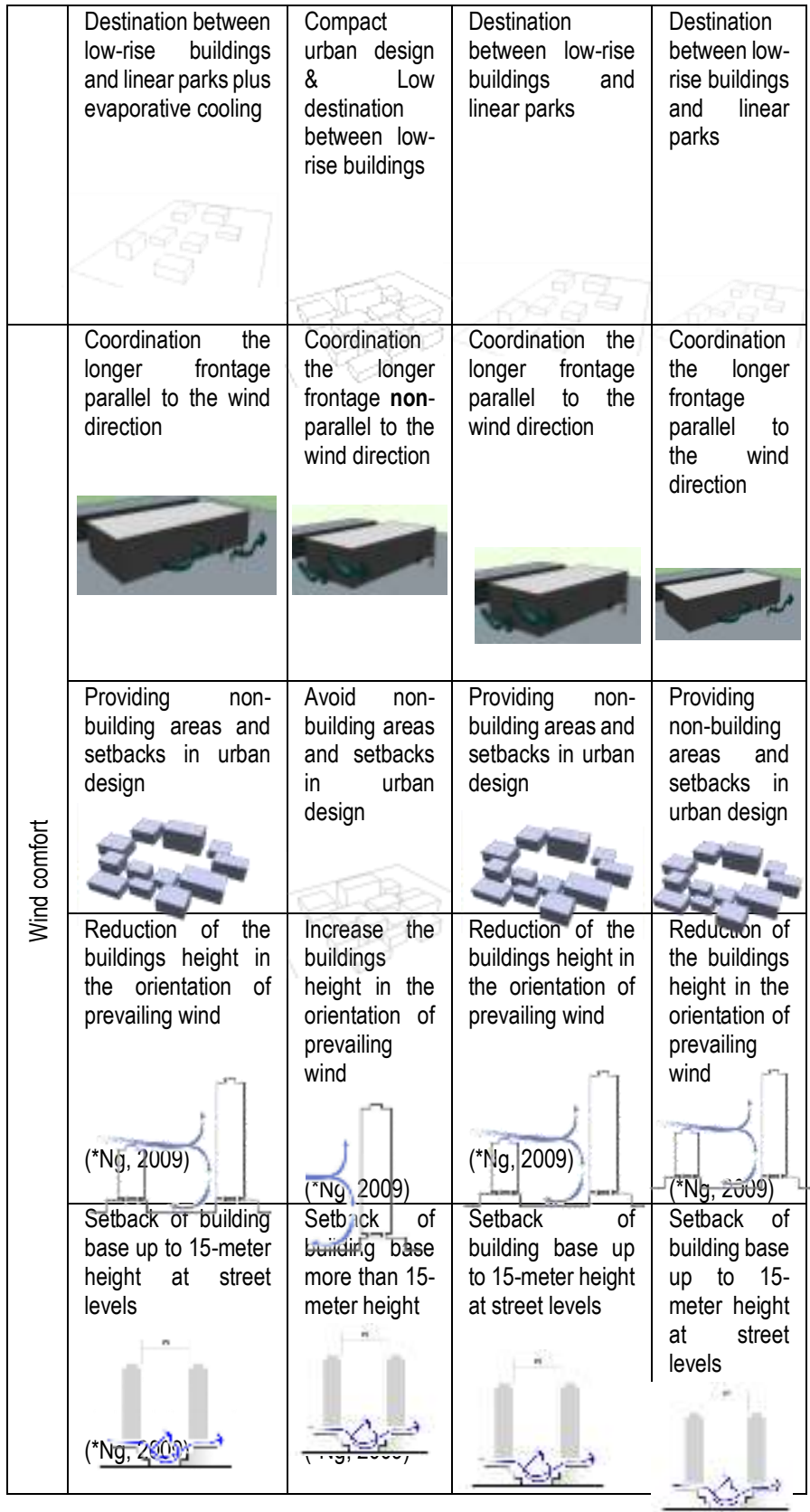




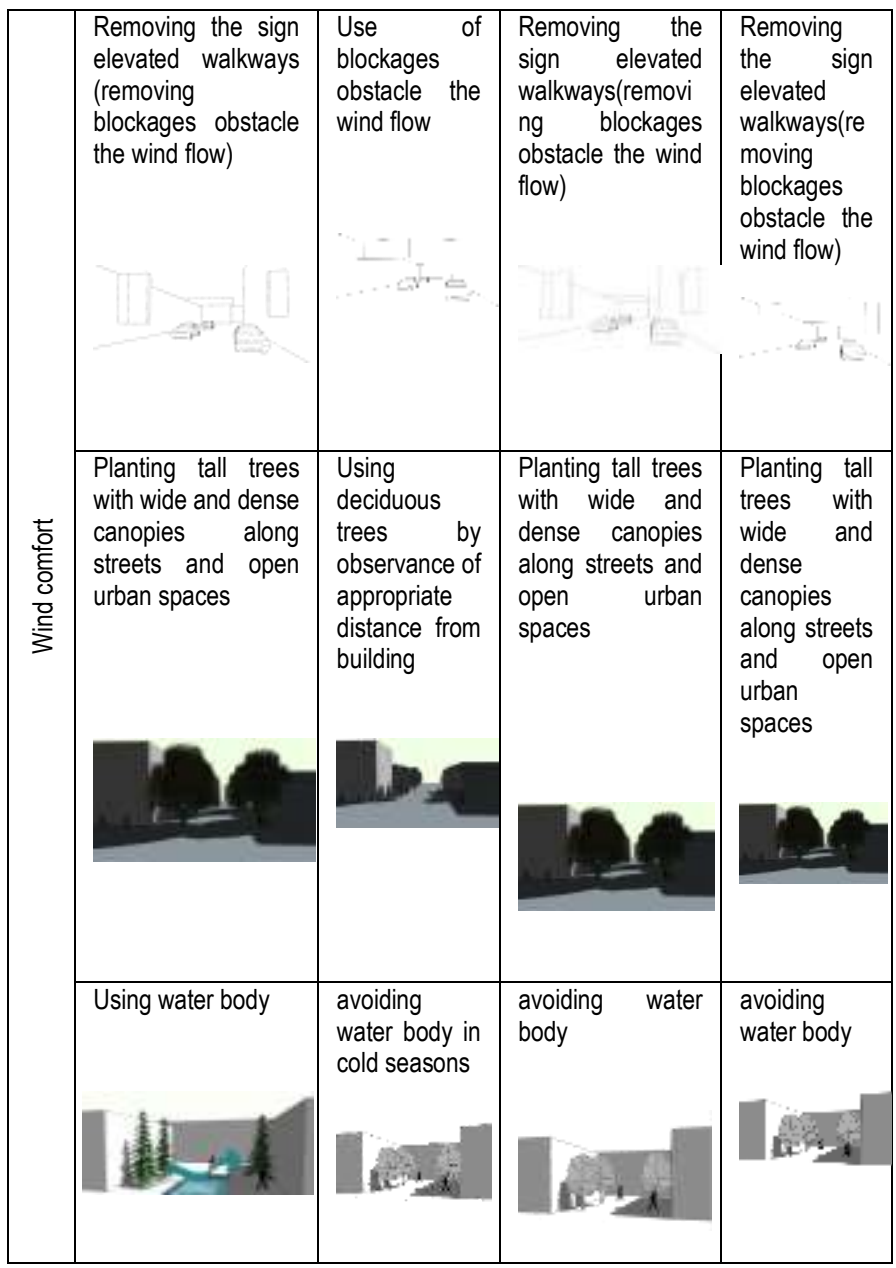

(Sources: Authors, 2015 (just some pictures with star $\left(^{*}\right)$ are from Ng, 2009))

\subsection{Conclusion}

Nowadays, decreased lees of people attendance within urban built environments, have caused interaction deficiency. In this way, urban open spaces have an important role in people attendance and quality of life in cities, such as increasing leisure time and their physical activity. It's necessary to promote suitable urban open spaces to create positive changes in society. There is no doubt that the creation of comfort zone for inhabitants in outdoor spaces is a challenge for designers who are deal with this issue. That is why the design can play a major role in the development of urban open spaces. Moreover, a 
successful open space is where acts friendly to humankind and invite people to gather together and interact with one another. This paper presents lots of research that have been devoted to studying climatology and human comfort features in urban environments and focused on guidelines of a design framework based on the relation among urban open spaces, comfort zone and people's interaction Conceptual scheme for urban open spaces has been extracted by use of several aspects of comfort zone, to grow people's interest in such spaces. These aspects of comfort consist of thermal and wind comfort. By this means, more effective frameworks aimed at increasing comfort zones among cities are being expressed in two categories of the wind and thermal. Hence, by using these guidelines in the design of open spaces, we can attain comfort zone in our cities and return people to urban open spaces. As a result, in this article, all the data are collected in a chart representing some conceptual guideline of urban open spaces. These data are concluded by consideration of human comfort.

In the paper, we have discussed human comfort features that is consist of lots of different aspects. We have limited our domain research to two major fields, thermal and wind comfort. Our recommendation for further research is to survey other aspects of human comfort such as acoustic comfort to derive its guidelines for urban open spaces.

\section{Acknowledgements}

The authors express their gratitude to Eng. Amin Yarmohammadian for his valuable comments and guidance to the project partners for providing field survey data.

\section{References}

Adawiyah Nasir, R., Sh Ahmad, S., \& Zain Ahmed, A. (2013). Physical Activity and Human Comfort Correlation in an Urban Park in Hot and Humid Conditions. AicE-Bs2013London-Asia Pacific International Conference on Environment-Behaviour Studies (pp. 598 - 609). University of Westminster, London, UK: Procedia - Social and Behavioral Sciences 105.

Ayman Mohamad, M. (2012). Quality of Life Indicators in Value Urban Areas: Kasr Elnile Street in Cairo. ASEAN Conference on Environment-Behaviour Studies (pp. 254-270). Bangkok, Thailand, 16-18 July 2012: AcE-Bs 2012 Bangkok.

Ayuni Shafie, F., Omar, D., \& Karuppannan, S. (2013). Environmental Health Impact Assessment and Urban Planning. AcE-Bs 2013 Hanoi-ASEAN Conference on Environment-Behaviour Studies (pp. 82 - 91). Hanoi Architectural University, Hanoi, Vietnam: Procedia - Social and Behavioral Sciences 85.

Hitam , M., \& Borhanb, H. (2012). FDI, Growth and the Environment: Impact on Quality of Life in Malaysia. ASEAN Conference on Environment-Behaviour Studies (pp. 332-342). Bangkok, Thailand, 16-18 July 2012: AcE-Bs 2012 Bangkok.

Bottema, M. (1999). Towards rules of thumb for wind comfort and air quality. Atmospheric Environment 33, 40094017. 
Chen , L., \& Ng, E. (2012). Outdoor thermal comfort and outdoor activities: A review of research in the past decade. cities 29, 118-125.

El-Husseiny, M.-A., \& Kesseiba, K. (2012). Challenges of Social Sustainability in Neo-liberal Cairo: Requestioning the role of public space. AicE-Bs 2012 Cairo-ASIA Pacific International Conference on Environment-Behaviour Studies (pp. 790 - 803). Mercure Le Sphinx Cairo Hotel, Giza, Egypt: Procedia - Social and Behavioral Sciences 68.

nikolopoulou, m., Baker, N., \& Steemers, K. (2001). Thermal Comfort in Outdoor Urban Spaces: Understading the Human Parameters. Solar Energy Vol. 70, 227-235.

Raja Ariffin, R., \& Khairi Zahari, R. (2013). Perceptions of the Urban Walking Environments. AicE-Bs2013LondonAsia Pacific International Conference on Environment-Behaviour Studies (pp. 589-597). University of Westminster, London, UK, : Procedia - Social and Behavioral Sciences 105.

Syariazulfa Kamaruddin, S., Fadhil Mohammad, M., \& Mahbub, R. (2013). Enhancing the Quality of Life by Adopting IBS: An economic perspective on mechanisation and automation. AicQoL 2013 Langkawi- AMER International Conference on Quality of Life (pp. 71-80). Holiday Villa Beach Resort \& Spa, Langkawi, Malaysia,: Procedia - Social and Behavioral Sciences 101.

Villadiego, K., \& André Velay-Dabat, M. (2014). Outdoor thermal comfort in a hot and humid climate of Colombia: A field study in Barranquilla. Building and Environment 75, 142-152.

Wan Jabarudin, W., \& Hanur Harith, Z. (2012). Harnessing Wind Comfort in Coastal Resort Malaysia. ASEAN Conference on Environment-Behaviour Studies (pp. 537-548). Bangkok, Thailand: AcE-Bs2012 Bangkok.

Blocken, B., Janssen, W., \& Hooff, T. v. (2012). CFD simulation for pedestrian wind comfort and wind safety in urban areas:General decision framework and case stud y for the Ein dhoven University campus. Environmental Modelling \& Software 30, 15-34.

Johansson, E., Thorsson, S., Emmanuel, R., \& Krüger, E. (2013). Instruments and methods in outdoor thermal comfort studies - The need for standardization. Urban Climate, 1-21.

Mohit, M. A. (2013). Quality of Life in Natural and Built Environment An Introductory Analysis. AMER International Conference on Quality of Life (pp. 33-43). Holiday Villa Beach Resort \& Spa, Langkawi, Malaysia, 6-8 April 2013: Procedia - Social and Behavioral Sciences 101.

Nadzira, N. M., Ibrahima, M., \& Mansor, M. (2014). Impacts of Coastal Reclamation to the Quality of Life:Tanjung Tokong community, Penang. AMER International Conference on Quality of Life (pp. 159-168). The Pacific Sutera Hotel, Sutera Harbour, Kota Kinabalu, Sabah, Malaysia: Procedia - Social and Behavioral Sciences 153.

$\mathrm{Ng}$, E. (2009). Policies and technical guidelines for urban planning of high-density cities - air ventilation assessmen $t$ (AVA) of Hong Kon g. Building and Environment 44, 1478-1488.

Ngesan, M., Abdul Karim, h., \& Zubir, S. (2012). Human Behaviour and Activities in Relation to Shah Alam Urban Park during Nighttime. AicE-Bs 2012 Cairo (Asia Pacific International Conference on Environment-Behaviour Studies), (pp. 427-438). Mercure Le Sphinx Cairo Hotel, Giza, Egypt: Procedia - Social and Behavioral Sciences.

Rabiatul Adawiyah, N., Sabarinah Sh , A., \& Azni Zain, A. (2013). Physical Activity and Human Comfort Correlation in an Urban Park in Hot and Humid Conditions. AicE-Bs2013London- Asia Pacific International Conference on Environment-Behaviour Studies (pp. 598 - 609). University of Westminster, London, UK,: Procedia - Social and Behavioral Sciences 105. 
Stathopoulosa , T., Wu , H., \& Zacharias. (2004). Outdoor human comfort in an urban climate. Building and Environment 39, 295-305.

Stathopoulosa, T., Wub, H., \& Zachariasc, J. (2004). Outdoor human comfort in an urban climate. Building and Environment 39, 297-305.

Taleghani, M., Kleerekoper , L., \& Tenpieri. (2014). Outdoor thermal comfort within five different urban forms in the Netherlands. Building and Environment, 1-14.

van Hovea, L., Jacobs, C., Heusinkveld, B., Elbers, J., van Driel, B., \& Holtslag, A. (2015). Temporal and spatial variability of urban heat island and thermal comfort within the Rotterdam agglomeration. Building and Environment $83,91-105$.

Walton, D. (2007). The relative influence of wind, sunlight and temperature onuser comfort in urban outdoor spaces. Building and Environment 42, $3166-3175$.

Ghobadian, V. (2000). climatology of Iranian traditional buildings . Tehran: Tehran university. Kasmaei, M. (2004). climate and architecture. Tehran: khak. 